\title{
Oxidative stress and antioxidant defences generated by solar UV in a Subantarctic marine phytoflagellate*
}

\author{
MARCELO PABLO HERNANDO ${ }^{1}$, GABRIELA FABIANA MALANGA ${ }^{1}$ \\ and GUSTAVO ADOLFO FERREYRA² \\ ${ }^{1}$ Centro Austral de Investigaciones Científicas (CADIC-CONICET) C.C. 92 (9410) Ushuaia, Tierra del Fuego, Argentina. \\ E-mail: hernandom@ciudad.com.ar \\ ${ }^{2}$ Instituto Antártico Argentino, Cerrito 1248 (1010) Buenos Aires, Argentina.
}

\begin{abstract}
SUMMARY: The reduction of the Antarctic stratospheric ozone resulted in significant increases in ultraviolet B radiation (UV-B, 280-320 nm) reaching the surface of the ocean. The main objective of this work was to study long-term (growth rate scale, days) stress responses (lipid oxidative damage, TBARS, and lipid soluble antioxidants) to UV-B and UV-A of a phytoflagellate species (Asteromonas sp.) isolated from a natural phytoplankton community of the Subantarctic Beagle Channel. The growth rate was inhibited by UV-B and UV-A radiation during the exponential phase. A marked increase in the TBARS content was observed on day 1 of the experiment, with significant differences between algae subjected to UVB and UV-A treatments, thus suggesting high damage to the cell membrane. During the second day of the experiment TBARS in UV-A treatments were higher than under photosynthetically active radiation (PAR). The concentration of TBARS decreased to the level of the PAR control on day 3, remaining low until the end of the experiment. Lipid antioxidant concentrations ( $\alpha$-tocopherol and $\beta$-carotene) were delayed with respect to variations in TBARS, showing maximum values on day 3 of the experiment. This coincided with the minimum TBARS concentrations in all treatments. The content of both antioxidants increased significantly in cultures exposed to UV-B and UV-A on days 3 and 4 . In Antarctic species (phytoflagellate Asteromonas sp., AP and diatom Thalassiosira sp., AT) $\alpha$-tocopherol was more abundant than $\beta$-carotene. The phytoflagellate species showed a lag in reaching the maximum content of both antioxidants in relation to AT, which reached the maximum concentration within a short time scale $(3 \mathrm{~h})$ suggesting a more rapid response to oxidative stress. AT was more resistant to UVR stress than the phytoflagellate species. Overall, our results show that UVR damage/repair balance involves the combined action of several internal factors in the cell.
\end{abstract}

Keywords: TBARS, $\beta$-carotene, $\alpha$-tocopherol, growth rate, ozone, UV radiation.

RESUMEN: ESTRÉS OXIDATIVO Y DEFENSAS ANTIOXIDANTES GENERADOS POR UV SOLAR EN UN FITOFLAGELADO MARINO SUBANTÁRTICO. - La reducción del ozono estratosférico antártico resulta en un incremento significativo de la radiación ultravioleta B (UV-B, 280-320 nm) en la superficie del océano. El principal objetivo de este trabajo fue un estudio de la respuesta a largo plazo al estrés producido por UV-B y radiación ultravioleta A (UV-A, 320-400 nm) en una especie de fitoflagelados (Asteromonas sp.). Dicha especie fue aislada de una comunidad subantártica natural del Canal Beagle y se analizó la tasa de crecimiento en escala diaria afectada por el daño oxidativo a lípidos, expresado como contenido de sustancias reactivas al ácido tiobarbitúrico (TBARS) y contenido de antioxidantes liposolubles. La tasa de crecimiento fue inhibida por la radiación UV-B y UV-A durante la fase exponencial. Se observó un incremento marcado en el contenido de TBARS el primer día del experimento, mostrando diferencias significativas entre algas sujetas a tratamientos de UV-B y UV-A, sugiriendo así un alto daño a la membrana celular. Durante el segundo día del experimento, los TBARS en el tratamiento de UV-A fueron mayores que aquellos en PAR $(400-700 \mathrm{~nm})$. La concentración de TBARS decreció al nivel del control PAR en el tercer día, permaneciendo baja hasta el final del experimento. Las concentraciones de antioxidantes lipídicos ( $\alpha$-tocopherol y $\beta$-carotene) estuvieron retrasadas con respecto a variaciones en TBARS, presentando valores máximos al tercer día de experimentación. Esto coincidió con las concentraciones mínimas de TBARS en todos los tratamientos. El contenido de ambos antioxidantes aumentó significativamente en cultivos expuestos a UV-B y UV-A durante los días 3 y 4 . En especies antárticas (Asteromonas sp., AP y Thalassiosira sp., AT) $\alpha$-tocopherol fue más abundante que $\beta$-carotene. Los flagelados 
mostraron un retraso en alcanzar el contenido máximo de ambos antioxidantes en relación con AT, las cuales presentaron la concentración máxima dentro de una escala de tiempo corta $(3 \mathrm{~h})$, sugiriendo una respuesta más rápida frente al estrés oxidativo. En conjunto, nuestro resultados muestran que el balance daño/reparación por UVR, involucra la acción combinada de varios factores internos en la célula.

Palabras clave: TBARS, $\beta$-caroteno, $\alpha$-tocoferol, tasa de crecimiento, ozono, radiación UV.

\section{INTRODUCTION}

During the last few decades, spring-time stratospheric ozone depletion over the Antarctic and the Southern Ocean (Lubin et al., 1989) has resulted in enhanced levels of ultraviolet-B (UV-B, 280-320 $\mathrm{nm}$ ) radiation reaching the Earth's surface. UV-B can reduce survival, growth and production of phytoplankton (Skerratt et al., 1998; Plante and Arts, 2000; Bischof et al., 2000). Ultraviolet radiation (UV-R, 280-400) has been shown to be very effective in inducing lipid peroxidation of biological membranes (Takeuchi et al., 1995; Hideg and Vass, 1996), polyunsaturated fatty acids (Yamashoji et al., 1979) and phospholipid liposomes (Pelle et al., 1990). Moreover, UV-B can destroy the natural lipid soluble antioxidants and promote the formation of lipid peroxidation products (Salmon et al., 1990; Malanga and Puntarulo, 1995; Estevez et al., 2001). In phytoplankton, there are four main defence mechanisms for avoiding the effects of ultraviolet radiation: namely, avoidance, screening, quenching and repair. The efficacy of each of these mechanisms is a function of the sensitivity of species, time exposure and climatic factors (Davidson, 1998). Several biological effects of UV-B involve endogenous photosensitising and formation of reactive oxygen species (Martin and Burch, 1990). There are a variety of sensitisers within cells which absorb UV-B. Interaction between excited sensitisers and triplet oxygen produces active oxygen intermediates (Ichiki et al., 1994), consisting of singlet oxygen $\left({ }^{1} \mathrm{O} 2\right)$, superoxide radical $\left(\mathrm{O}^{-}\right)$, hydroxyl radical $(\mathrm{OH})$ and hydrogen peroxide $\left(\mathrm{H}_{2} \mathrm{O}_{2}\right)$ (Ichiki et al., 1994). One of the possible mechanisms that could counteract the damage generated by UV-B radiation induced oxidative stress is the synthesis of both enzymatic and non-enzymatic antioxidants (Davidson, 1998; Niyogi, 1999). The non-enzymatic antioxidants are generally small molecules, such as ascorbate and glutathione acting in the aqueous phase, whereas the lipophilic antioxidants (such as $\alpha$-tocopherol and $\beta$ carotene) are active in the membrane environment. Especially $\alpha$-tocopherol is known for its protective effect (Burton et al., 1982) against lipid peroxida- tion of biological membranes via peroxyl and alkoxyl radical scavenging. By contrast, the main function of $\beta$-carotene is photoreceptive, because it acts as a pigment antenna in the photosynthesis process. Relatively low concentrations of $\beta$-carotene protect against oxidative damage initiated by singlet oxygen.

Growth and biomass accumulation will result from complex interactions between harmful direct and indirect effects of UV-R and a series of counteracting repair mechanisms (Lesser et al., 1994). UV$\mathrm{R}$ induced biological damage and the development of defence strategies has been studied in both Antarctic (Karentz et al., 1991; Helbling et al., 1996; Neale et al., 2002) and Subantarctic organisms (Hernando et al., 1998). However, no information is available about UV-induced oxidative stress for the phytoplankton from the Beagle Channel. The basis for this concern is that although the decrease in ozone concentration occurs mainly in the polar vortex above the Antarctic continent, the so-called "ozone hole" is a dynamic system which can be found in the south of the American continent (Orce et al., 1995).

The main aim of this work was to study immediate effects on growth rate and oxidative stress parameters in response to UV-B and UV-A in phytoplankton from Subantarctic waters (phytoflagellate Asteromonas $s p$.) as a function of time and UV-R exposure under culture conditions.

\section{MATERIALS AND METHODS}

\section{Culture conditions}

The experiments were carried out in the Beagle Channel (CADIC, Ushuaia, 54 ${ }^{\circ} 52^{\prime} \mathrm{S}, 68^{\circ} 18^{\prime} \mathrm{W}$ ) (Fig. 1). Surface water samples were taken using a five-litre Niskin bottle and maintained in the laboratory at $8^{\circ} \mathrm{C}$. Phytoflagellate (Asteromonas sp.) single cells were isolated with a micropipe using an inverted microscope, and inoculated into $200 \mathrm{ml}$ flasks with filtered seawater plus $\mathrm{F} / 2$ culture medium (Guillard, 1975). Before the experiments, cultures 


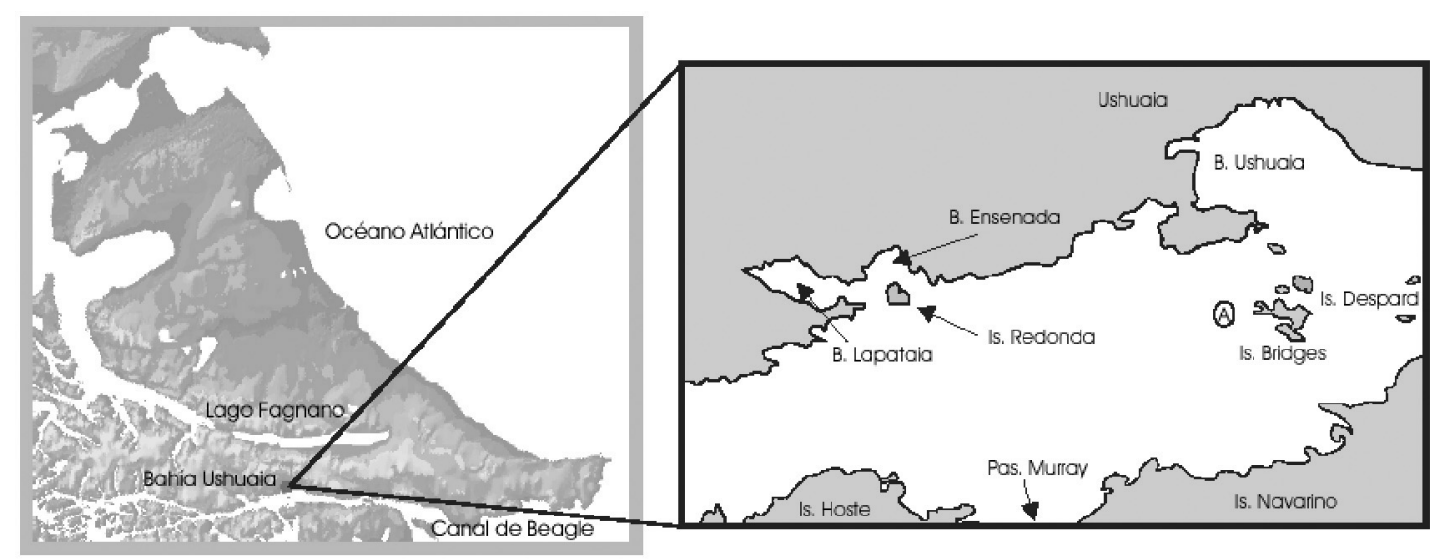

Fig. 1. - Map with sample location (A) in the Beagle Channel, Ushuaia, Argentina.

were grown at an irradiance of $210 \mathrm{uE} \cdot \mathrm{m}^{-2} \cdot \mathrm{s}^{-1}$ photosynthetically active radiation (PAR), provided by 'cool-white' fluorescent bulbs on $12 / 12 \mathrm{~h}$ at $8^{\circ} \mathrm{C}$. Once exponential growth was reached, aliquots of the mono-specific culture were inoculated into a series of $500 \mathrm{ml}$ vessels and then exposed to solar radiation from February 24 to March 2, 1998. For chlorophyll- $a$ analyses $20 \mathrm{ml}$ water was filtered through Whatman fibreglass filters (GF/F, $25 \mathrm{~mm}$ ), followed by the extraction of pigments in absolute methanol (Holm-Hansen and Riemann, 1978). Subsamples for cell counts were kept in dark bottles and fixed with formalin previously neutralised with sodium borate (final concentration $0.4 \% \mathrm{w} / \mathrm{v}$ ). All the samples were counted with an inverted microscope using a Sedgwick-Rafter counting slide according to Villafañe and Reid (1995).

\section{Experimental design}

Cells were exposed in parallel to three irradiance treatments: PAR (control, 400-700 nm), UV-A (PAR + Ultraviolet-A radiation, 320-400 NM) and UV-B (PAR + UV-A + UV-B, 280-320). Cylindrical UVtransparent quartz flasks were used for exposure of phytoplankton. For the UV-A treatment, the bottles were covered with Mylar foil (DuPont country, which has 50\% transmission at $323 \mathrm{~nm}$ ) and PAR controls were performed with cylindrical Plexiglass flasks (UF3) (Röhm and Haas country) which cut off UV radiation (Hernando and San Román, 1999). Three replicate samples were used for each of the treatments and controls. Culture medium was added to the different treatments at the time 0 (to) of the experiments. The algae were exposed to natural sunlight in an outside tank, through which thermostated sea water could be pumped in order to maintain the temperature approximately constant (around $10^{\circ} \mathrm{C}$ ). $80 \mathrm{ml}$ samples were taken daily at 9 a.m. to determine the chlorophyll concentration, the cell number, the content of thiobarbituric acid reactive substances, the index of lipid peroxidation (TBARS) and the $\alpha$-tocopherol and $\beta$-carotene content.

\section{Irradiance measurements}

Incident solar radiation was monitored continuously during the experiment using a spectroradiometer (model GUV 510, Biospherical Instruments, Inc.), which records irradiances at four wavelengths in the ultraviolet region $(305,320,340$ and $380 \mathrm{~nm}$ ), and Photosynthetic Available Radiation (PAR, 400-700 nm). Data were recorded at a frequency of one per minute at a site close to the experimental setup. The equation from Orce et al. (1997) was used in order to calculate UV-B and UV-A doses in $\mathrm{kJ} . \mathrm{m}^{-2}$.

\section{Growth measurements}

Cell instantaneous growth rate was determined according to the following equation:

$$
\mu=\ln \left(\mathrm{N}_{1} / \mathrm{N}_{\mathrm{n}-1}\right)
$$

where $\mu$ is a specific rate constant (d-1), $\mathrm{t}_{1}$ is the time of measurement, and $t_{n-1}$ is the time of the previous one, $\mathrm{N}_{1}$ is the cell concentration at time $\mathrm{t}_{1}$, and $N_{n-1}$ is the cell concentration at time $t_{n-1}$.

\section{Lipid peroxidation}

Fifteen $\mathrm{ml}$ cell suspensions were centrifuged for $10 \mathrm{~min}$. at $12000 \mathrm{~g}$. The pellet was suspended in 2 
$\mathrm{ml}$ of $120 \mathrm{mM} \mathrm{KCl}$ in $50 \mathrm{mM}$ potassium phosphate buffer ( $\mathrm{pH} 7.0)$, sonicated and centrifuged for 10 min. at $600 \mathrm{~g}$. A $0.8 \mathrm{ml}$ volume aliquot of the supernatant was treated with $0.7 \mathrm{ml} \mathrm{30 \%} \mathrm{(w/v)} \mathrm{TCA} \mathrm{and}$ $50 \mathrm{mM}$ potassium phosphate buffer $(\mathrm{pH} 7.0)$ and brought to a final volume of $2 \mathrm{ml}$ before centrifugation. $0.2 \mathrm{ml}$ of $3 \%(\mathrm{w} / \mathrm{v})$ SDS and $0.05 \mathrm{ml}$ of $4 \%$ (w/v) butylated hydroxytoluene (BHT) in ethanol were added to $1 \mathrm{ml}$ of the supernatant. After mixing, $2 \mathrm{ml}$ of $0.1 \mathrm{~N} \mathrm{HCl}, 0.3 \mathrm{ml}$ of $10 \%$ (w/v) phosphotungstic acid and $1 \mathrm{ml}$ of $0.7 \%(\mathrm{w} / \mathrm{v}) 2$-thiobarbituric acid were added. The mixture was heated at $95^{\circ} \mathrm{C}$ in a water bath for $45 \mathrm{~min}$. and $5 \mathrm{ml}$ of $\mathrm{n}$ butanol was added, whereafter the samples were vortexed and centrifuged at $600 \mathrm{~g}$ for $10 \mathrm{~min}$. The fluorescence of the organic layer (upper layer) was measured at $515 \mathrm{~nm}$ excitation and $555 \mathrm{~nm}$ emission. The values were expressed as nmol TBARS (malondialdehyde equivalents) per $10^{4}$ cells. Malondialdehyde standards were prepared from 1,1,3,3tetramethoxypropane (Fraga et al., 1987).

\section{Lipid soluble antioxidants}

The content of $\alpha$-tocopherol and $\beta$-carotene in the cell homogenates was quantified by filtering a 5 ml sample by reverse-phase HPLC with electrochemical detection using a Bioanalytical Systems LC-4C amperometric detector with a glassy carbon working electrode at an applied oxidation potential of $0.6 \mathrm{~V}$ (Desai, 1984). Extraction from the samples was performed with $1 \mathrm{ml}$ of methanol and $4 \mathrm{ml}$ of hexane. After centrifugation at $600 \mathrm{~g}$ for $10 \mathrm{~min}$., the hexane phase was removed and evaporated to dryness under $\mathrm{N}_{2}$. Extracts were dissolved in methanol:ethanol $(1: 1 \mathrm{v} / \mathrm{v})$ and injected for HPLC analysis, HPLC conditions were:

isocratic reversed phase, column: Supelcosil LC$8 ; 3.3 \mathrm{~cm} \times 4.6 \mathrm{~mm} \times 3 \mu \mathrm{m}$.

mobile phase: $20 \mathrm{mM}$ lithium perclorate in methanol/water 99/1 (v/v).

flow rate: $0.8 \mathrm{ml} / \mathrm{min}$.

retention time: $\alpha$-Tocopherol $=0.8 \mathrm{~min}$ and $\beta$ carotene $=1.6 \mathrm{~min}$.

d, l- $\alpha$-tocopherol from synthetic phytol (Sigma) and $\beta$-carotene were used as standards.

\section{Statistical analyses}

Parametric analysis of variance repeated measures were applied to test the significance of the differences observed between treatments. Data were
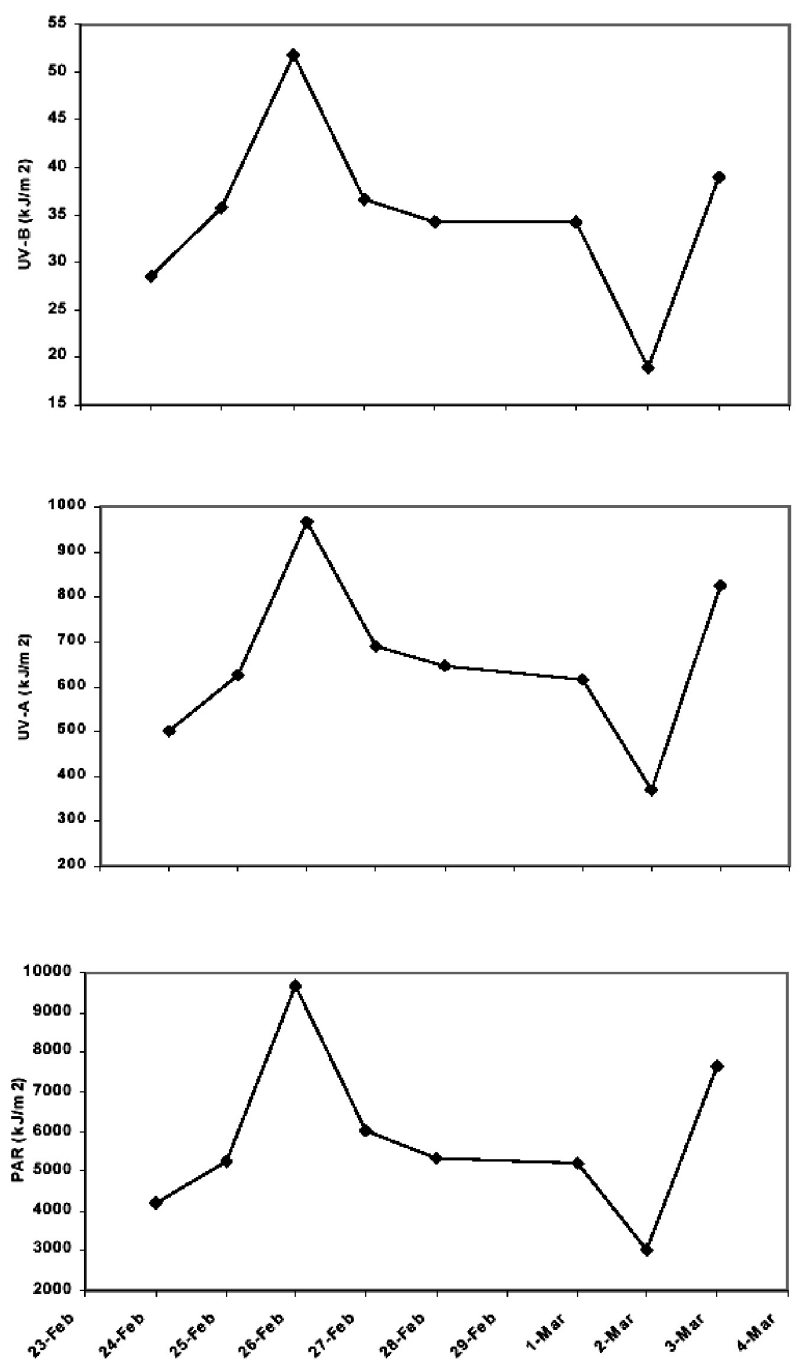

Fig. 2. - Variations in UVR doses at the Beagle Channel from February 24 to 28,1998 . (A) UVB doses $(280-320 \mathrm{~nm})$, in $\mathrm{kJ} / \mathrm{m}^{2}$; (B) UVA doses (320-400 $\mathrm{nm}$ ), in $\mathrm{kJ} / \mathrm{m}^{2}$; (C) PAR (400-700 $\mathrm{nm}$ ), in $\mathrm{kJ} / \mathrm{m}^{2}$. Each point represents the integrated value doses for each experimental day.

checked prior to the analyses in order to verify the homoscedacity and normality requirements of the ANOVA. When such requirements were not satisfied, a standard transformation of data was applied (ln $\mathrm{x}$ on TBARS and $1 /$ squar root $\mathrm{x}$ on $\alpha$-tocopherol and $\beta$-carotene data). Days of exposure and treatments were used as factors. When the interaction was significant, the differences in treatment for each day were analysed.

In all cases the exponential phase of the growth rate of PAR treatment was taken as control.

\section{RESULTS}

The data in Figure 2 show the variation of surface daily doses of UV-B, UV-A and PAR through- 

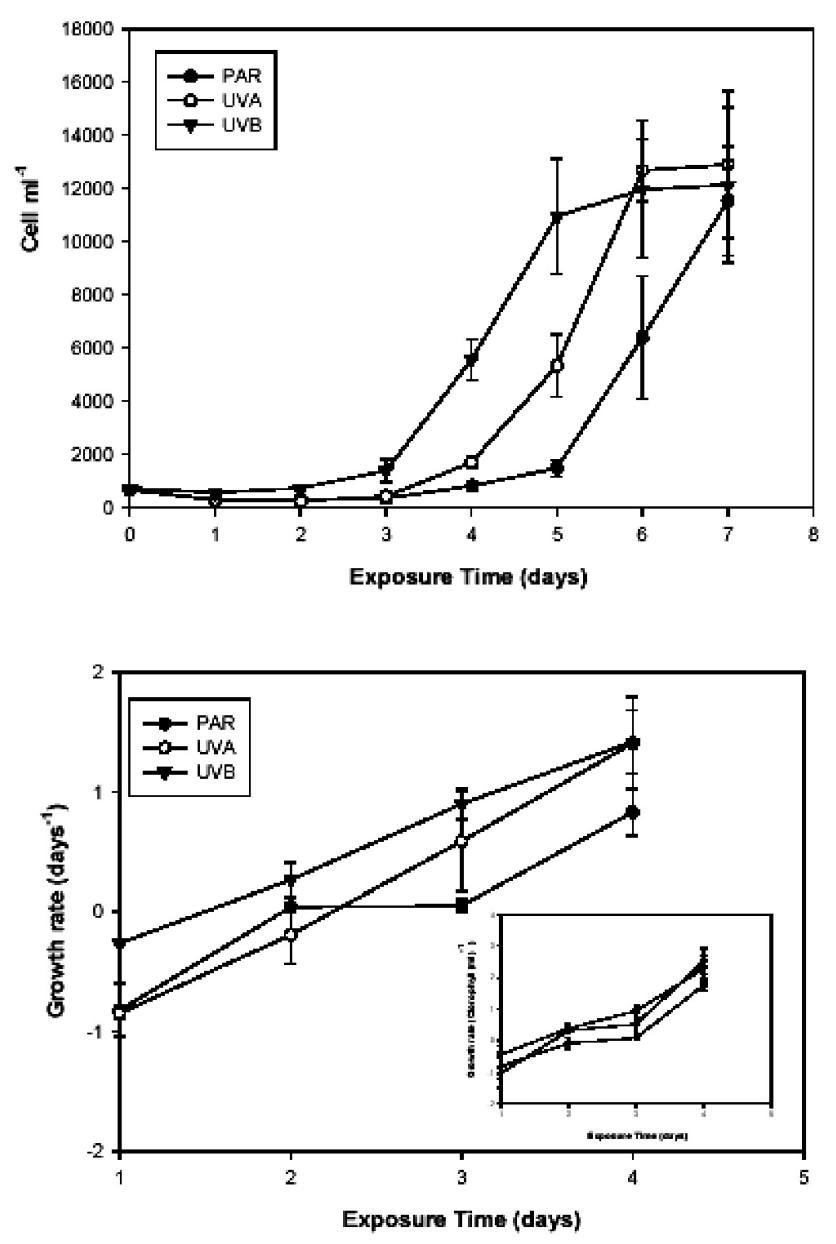

Fig. 3. - A, cell density during the complete experiment. B, exponential instantaneous growth rate of phytoflagellate $\cdot \mathrm{ml}^{-1}$ using cell number when exposed to natural solar radiation for 4 days. Insert: instantaneous growth rate using chlorophyll- $a$. UV-B represents those algae exposed to UVB+UVA+PAR, UV-A those exposed to UVA+PAR, and PAR those exposed to PAR. Each point represents the mean $+/-$ SD.

out the study period (Orce et al., 1997). During the period of exponential growth rate, the average daily doses from 24 to 28 February 1998 were $37 \mathrm{~kJ} / \mathrm{m}^{2}$ for UV-B, $685 \mathrm{~kJ} / \mathrm{m}^{2}$ for UV-A and $6092 \mathrm{~kJ} / \mathrm{m}^{2}$ for PAR. At that time ozone concentration was often higher than 295 D.U., and the average was 285 D.U. The variability noted in the data was primarily due to changes in the degree of cloud cover, with a maximal dose recorded on day three of the experiment (February 26) (Fig. 2).

Figure $3 \mathrm{a}$ shows the temporal evolution of cell density during the experiment. The triggering of exponential growth was treatment-dependent, starting on days 3, 4 and 5 for PAR, UV-A and UV-B treatments respectively. Once exponential growth was reached, growth rate was identical for the three treatments. In order to understand in more detail cell changes in the different treatments before the period of exponential growth, instantaneous growth rates were calculated for the first 4 days of the experiment. Instantaneous growth rate was significantly inhibited in the UV-A and UV-B treatments respectively, in comparison with the PAR treatment (Table $1 \mathrm{~A})$. Considering the days factor (Table $1 \mathrm{~A}$ ), there was a significant increase between each day of exponential instantaneous growth rate. The growth rate evaluated using chlorophyll- $a$ content showed the same profile (Fig. $3 b$ inset). During the exponential growth phase, TBARS concentrations in algae exposed only to PAR did not show any significant difference between days ( $P>0.05$, Fig. 4). In contrast, UV-A and UV-B treatment showed a significant increase (Table $1 \mathrm{~B}, \mathrm{P}<0.01$ ) on day one without showing differences between days $(\mathrm{P}>0.05)$. On the following days TBARS concentrations decreased significantly, showing significant differences from the PAR treatment on day 2 in the UV-B $(\mathrm{P}<0.001)$ and UV-A treatment $(\mathrm{P}<0.01$, Table 1B and Fig. 4). On day three and four no differences were found between any treatments (Table $1 \mathrm{~B}$ and Figure 4). The maximum TBARS content in both UV-R treatments was lagged by one day, with the higher values on days 1 and 2 for the UV-B and UV-A treatments respectively.

No significant differences were observed between days in the content of lipid soluble antioxidant ( $\alpha$-tocopherol and $\beta$-carotene) on phytoflagellates exposed to PAR ( $P>0.05$, Fig. 5a, b).

Except on day 1 for $\alpha$-tocopherol in the UV-B treatment, no significant differences in the content of lipid soluble antioxidants were observed during the first two days of the experiment in algae exposed to UV-B and UV-A treatments, as compared to the PAR control (P $>0.05$, Fig. $5 \mathrm{a}, \mathrm{b})$.

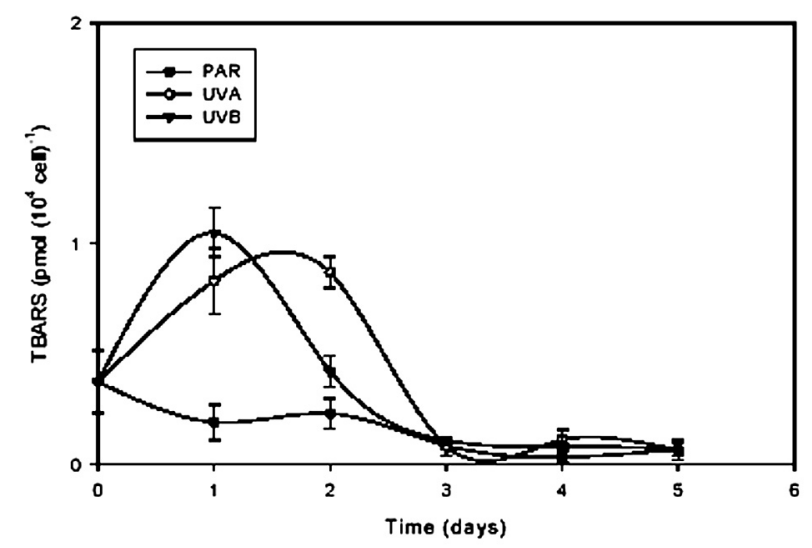

Fig. 4. - Effect of UV radiation on lipid peroxidation (TBARS content) in phytoflagellates as a function of exposure time. Each point represents the mean $+/-\mathrm{SD}$. 
TABLE 1. - Results of parametric analysis of variance repeated measures showing the significance of UV effects on the exponential instantaneous growth rate of a Subantarctic phytoflagellate (Asteromonas sp.). Note: The factors are Day (1, 2, 3 and 4) and Treatment (UV-B, UV$\mathrm{A}$ and PAR), and the variable was $\mu$ (instantaneous growth rate). The same letter means no significant differences. For each factor, the differences were significant at $\mathrm{P}<0.01(*)$ or $\mathrm{P}<0.001(* *)$ (Tuckey test).

\begin{tabular}{|c|c|c|c|c|c|}
\hline $\begin{array}{l}\text { A } \\
\text { Factor }\end{array}$ & $\begin{array}{c}\text { Growth rate } \\
\text { F }\end{array}$ & Sign. Level & $\begin{array}{l}\text { B } \\
\text { Factor }\end{array}$ & $\begin{array}{c}\text { TBARS } \\
\text { F }\end{array}$ & Sign. Level \\
\hline $\begin{array}{l}\text { Day } \\
\text { Treatment } \\
\text { Interaction } \\
\text { Treatment } \\
\text { UVB } \\
\text { UVA } \\
\text { PAR } \\
\\
\text { Day } \\
1 \\
2 \\
3 \\
4\end{array}$ & $\begin{array}{c}68.02 \\
408.02 \\
2.36 \\
\text { Means } \\
0.02 \mathrm{a} \\
0.24 \mathrm{~b} \\
0.53 \\
\\
\\
-0.65 \\
0.018 \\
0.51 \\
1.17 \mathrm{~d}(* *)\end{array}$ & $\begin{array}{c}<0.0001 \\
<0.001 \\
0.08 \\
\text { Homog. Group } \\
(* *) \\
(* *) \\
\mathrm{c}(* *)\end{array}$ & $\begin{array}{l}\text { Day } \\
\text { Treatment } \\
\text { Interaction } 3.97 \\
\text { Day 1 } \\
\text { UVB } 0.043 \\
\text { UVA -0.2 } \\
\text { PAR } \\
\text { Day 2 } \\
\text { UVB -0.88 } \\
\text { UVA } \\
\text { PAR } \\
\text { Day 3 } \\
\text { UVB -2.2 } \\
\text { UVA -2.6 } \\
\text { PAR - 2.41 } \\
\text { Day 4 } \\
\text { UVB -2.72 } \\
\text { UVA -2.26 } \\
\text { PAR -3.44 }\end{array}$ & $\begin{array}{c}23.44 \\
65.97 \\
< \\
\text { Means } \\
\mathrm{a} \\
\mathrm{a} \\
-1.72 \\
\\
\mathrm{a} \\
-0.15 \\
-1.49 \\
\\
\mathrm{a} \\
\mathrm{a} \\
\mathrm{a} \\
\\
\mathrm{a} \\
\mathrm{a} \\
\mathrm{a}\end{array}$ & $\begin{array}{c}<0.01 \\
<0.001 \\
0.01 \\
\text { Homog. Group } \\
\text { b (**) } \\
\\
\text { b (**) } \\
\mathrm{c}(*)\end{array}$ \\
\hline $\begin{array}{l}\text { C } \\
\text { Factor }\end{array}$ & $\underset{\mathrm{F}}{\alpha \text {-tocopherol }}$ & Sign. Level & $\begin{array}{l}\text { D } \\
\text { Factor }\end{array}$ & $\begin{array}{c}\beta \text {-carotene } \\
\mathrm{F}\end{array}$ & Sign. Level \\
\hline $\begin{array}{l}\text { Day } \\
\text { Treatment } \\
\text { Interaction } \\
\text { Day 1 } \\
\text { UVB } \\
\text { UVA } \\
\text { PAR } \\
\text { Day 2 } \\
\text { UVB } \\
\text { UVA } \\
\text { PAR } \\
\text { Day 3 } \\
\text { UVB } \\
\text { UVA } \\
\text { PAR } \\
\text { Day 4 } \\
\text { UVB } \\
\text { UVA } \\
\text { PAR }\end{array}$ & $\begin{array}{c}32.02 \\
166.19 \\
112.58 \\
\text { Means } \\
0.58 \\
0.17 \mathrm{~b} \\
0.13 \mathrm{bc} \\
0.16 \\
0.18 \\
0.13 \\
\\
0.049 \mathrm{a} \\
0.084 \mathrm{~b} \\
0.099 \\
\\
0.08 \\
0.11 \\
0.15\end{array}$ & $\begin{array}{c}<0.01 \\
<0.01 \\
<0.01 \\
\text { Homog. Group } \\
\mathrm{a} \\
(* *) \\
(* *) \\
\mathrm{a} \\
\mathrm{a} \\
\mathrm{a} \\
\\
(* *) \\
(* *) \\
\mathrm{c}(* *) \\
\mathrm{a} \\
\mathrm{a} \\
\mathrm{b}(*)\end{array}$ & $\begin{array}{l}\text { Day } \\
\text { Treatment } 48.93 \\
\text { Interaction } \\
\text { Day 1 } \\
\text { UVB 0.24 } \\
\text { UVA 0.26 } \\
\text { PAR 0.32 } \\
\text { Day 2 } \\
\text { UVB } 0.22 \\
\text { UVA } 0.19 \\
\text { PAR 0.22 } \\
\text { Day 3 } \\
\text { UVB 0.04 } \\
\text { UVA 0.03 } \\
\text { PAR } \\
\text { Day 4 } \\
\text { UVB } 0.05 \\
\text { UVA 0.12 } \\
\text { PAR }\end{array}$ & $\begin{array}{c}63.88 \\
< \\
4.97 \\
\text { Means } \\
\text { a } \\
\text { a } \\
\text { a } \\
\\
\text { a } \\
\text { a } \\
\text { a } \\
\\
\text { a } \\
\text { a } \\
0.16 \\
\\
\text { a } \\
\text { a } \\
0.26\end{array}$ & $\begin{array}{c}<0.001 \\
0.001 \\
<0.01 \\
\text { Homog. Group }\end{array}$ \\
\hline
\end{tabular}
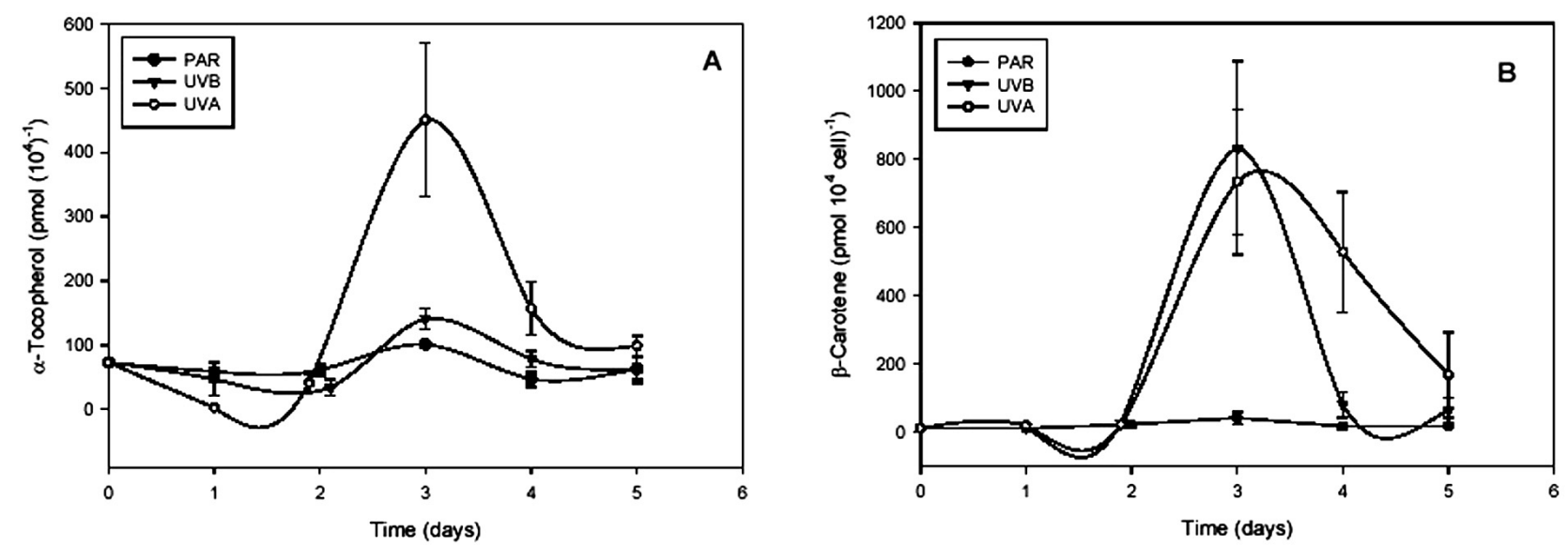

Fig. 5. - Effect of UV radiation on antioxidant lipid soluble in phytoflagellates as a function of exposure time. A, $\alpha$-tocopherol content; B, $\beta$-carotene content. Each point represents the mean $+/-\mathrm{SD}$. 
The $\alpha$-tocopherol content showed a significant decrease on the first day of the exposure for algae exposed to the UV-B treatment $(\mathrm{P}<0.01$, Table $1 \mathrm{C})$, then increased sharply and reached maximum values of around 450 pmol $10^{4}$ cell $^{-1}$ on day three. Significant differences $(\mathrm{P}<0.01)$ were found on that day with PAR. Afterwards, the content of $\alpha$-tocopherol decreased again toward the end of the measurements, showing values that were not different from those observed for the PAR and UV-A treatments $(\mathrm{P}>0.05)$. The same profile was observed for the $\alpha$-tocopherol content in the UV-A treatment, but in this case the concentrations were lower than in the previous one (maximum concentration around 150 pmol $10^{4}$ cell- $^{-1}$ on day three) (Fig. 5 a).

Like that of a-tocopherol, the b-carotene content increased steeply on day three of the experiment in the UV-B and UV-A treatments (around 800 pmol. $10^{4}$ cell $^{-1}$ ) (Fig. 5b). Contrasting with the previous results (Fig. 5a), no significant differences were observed between the UV-A and UV-B treatments. A marked decrease was observed afterwards, being smoother in the UV-B than in the UV-A treatment. No significant differences were observed on day five between the three treatments $(\mathrm{P}>0.05$, Fig. $5 b)$.

\section{DISCUSSION}

UV-B exposure has been demonstrated to stimulate the generation of ROS. The effects of UV-B on cell membranes are probably related to oxidation by free radicals (Predieri et al., 1995). Therefore, the increase in the TBARS content is more precisely an indicator of a general UV-B-induced oxidative damage.

Significant differences in the TBARS content were observed in algae subjected to UV-B and UV$\mathrm{A}$ at the beginning of the experiment, indicating that UV-B and UV-A radiation induced oxidative stress under our experimental conditions. This was accompanied by an inhibition of growth rate by UV-B and UV-A radiation during the exponential phase. In addition, chlorophyll levels decreased in both treatments (Fig. 3b inset), thus suggesting a reduction of photosynthetic capacity (Malanga et al, 1997). This is consistent with the idea that, under UV-B stress conditions, microalgae sacrifice their photosynthetic capacity of the chloroplast in order to protect the rest of the cell (Strid, 1993; Mackerness et al., 1998). This led us to evaluate lipid soluble antioxidants, as the susceptibility to oxidative damage related to the balance between antioxidants and pro-oxidants. The decrease in TBARS levels in the UV-B and UV-A treatments on day three coincided with an increase in $\alpha$-tocopherol and of $\beta$-carotene content. The subsequent decrease in tocopherol content suggests an active generation of active oxidant species during exposure of growing cultures, leading to the consumption of antioxidants. The connection between oxidative damage and antioxidant defence mechanisms has been postulated in both animal and plant cells (Kingston-Smith and Foyer, 2000).

$\beta$-carotene concentrations in the PAR controls were lower than those of $\alpha$-tocopherol. $\beta$-carotene can directly quench singlet oxygen or can prevent the formation of a chlorophyll triplet excited state (Young et al., 1997). Lipophilic molecules such as $\alpha$-tocopherol are able to deactivate ${ }^{1} \mathrm{O}_{2}$, reduce $\mathrm{O}_{2}$ and terminate lipid radical chain reactions (Polle and Rennenberg, 1994), and are regenerated by ascorbate. The $\beta$-carotene content increased significantly (Fig. 5b) in cultures exposed to UV-B and (contrasting with $\alpha$-tocopherol results) UV-A on day three of incubation. These results could be explained by considering that in the UV-A treatment there was a significant increase in the TBARS content on day one and two of incubation. There was a significant decrease in $\beta$-carotene on day four and five in the UV-A treatment. Such results could indicate consumption or a decreased synthesis, suggesting a significant role of this antioxidant in protection against the damage produced by UV-A radiation. This could explain the tendency to decrease the inhibition in the UV-A treatment for the growth rate on days three and four (35\% and 1\% compared with the PAR treatment respectively; Fig. 3).

Jagtap and Bhargava (1995) postulated that the ability of plants to manipulate the antioxidant metabolism under stress conditions appears to be critical to stress tolerance. However, despite the fact that in the UV-A treatment the inhibition has a tendency to be lowest at the end of the exponential growth, in the UV-B treatment the inhibition remains high (95\% and $42 \%$ for days three and four respectively, Fig. 3). Clearly, the damage (TBARS) was low on days 4 and 5 , so protection was present somehow, but perhaps in the form of lipid antioxidants. Perhaps by that time the cells had found other ways to screen harmful UV.

These results could be explained considering that other stress conditions, such as DNA damage, could be involved in algae exposed to UV-B radiation (Karentz et al., 1991). Our data clearly show that 
under our experimental design, TBARS production was independent of the doses received by the cultures $\left(R^{2}=0.27, n=9\right)$ but dependent on the quality of the radiation. Maximum concentrations of cells were observed on day one and two of the experiment for the UV-B and UV-A treatments respectively, while the maximum doses were measured one day later (Fig. 2). Experimental observations in the Antarctic (Hernando, unpublished data) show that the same non-enzymatic antioxidants considered during this study are produced at lower concentrations. The maximum concentrations of $\alpha$ tocopherol measured were around 150 and $30 \mathrm{pmol}$ 10-4 cell-1 for a phytoflagellate and a diatom (Thalassiosira sp.) isolated from Antarctic coastal waters respectively. This is approximately $30 \%$ and $7 \%$ of the concentrations determined in the Beagle Channel. In addition, the Antarctic phytoflagellate and the diatom produced only $10 \%$ and $1.5 \%$ of $\beta$-carotene, as compared with the algae from Beagle Channel. This demonstrates more pronounced responses to UVR in the phytoflagellate from the Subantarctic environment. On the other hand, other defence mechanisms probably help the cells to cope with UVR damage, such as the synthesis of MAAs, which probably plays a significant role in photoprotection of Antarctic phytoplankton (Hernando et al., 2002). Other mechanisms to be considered in further studies are carotenoids, the chlorophyll/carotenoid ratio and antioxidant enzymes, which will all confer an adaptive capacity.

A significant result emerging from this experiment is that UVR-induced oxidative stress, expressed here as membrane damage, affected the starting time of exponential growth, but not final biomass accumulation or growth during the exponential phase. This suggests that cells were able to cope with UV damage, and that the only significant effect was the delay in the timing of exponential growth. The consequences of these changes need to be considered in the framework of the natural environment, in order to understand the effects of UV-R on the timing and dynamics of phytoplankton blooms.

Overall, our results support the idea that UVR damage/repair balance involves the combined action of several internal factors in the cell. Taken as a whole, the data presented here strongly suggest that exposure to mild oxidative stress initiates a series of adaptive responses that provide increased protection against more severe stress.

\section{ACKNOWLEDGEMENTS}

This study was supported by grants from the Univ. of Buenos Aires, and CONICET. G.F. is a career researcher from IAA, G.M. is a career research fellow from CONICET. The authors are grateful to M. Barbagallo for technical assistance and to Dr. S. Puntarulo for a critical reading of the manuscript.

\section{REFERENCES}

Bischof, K., D. Hanelt and C. Wiencke. - 2000. Effects of ultraviolet radiation on photosynthesis and related enzyme reactives of marine macroalgae. Planta, 211: 555-562.

Burton, G.W., A. Joyce and K.U. Ingold. - 1982. First proof that vitamin $\mathrm{E}$ is major lipid-soluble, chain-breaking antioxidant in human blood plasma. Lancet, 2: 327.

Davidson, A.T. - 1998. The impact of UVB radiation on marine plankton. Mutat. Res., 422: 119-129.

Desai, I. - 1984. Vitamin E analysis methods for animal tissues. Method. Enzymol., 105: 138-146.

Estevez, M.S., G. Malanga and S. Puntarulo. - 2001. UV-B effects on Antarctic Chlorella sp cells. J. Photoch. Photobio., 62: 19-25.

Fraga, C.G., B.E. Leibovitz and A.L. Tappel. - 1987. Halogenated compounds as initiators of lipid peroxidation in tissue slices. Free Radic. Bio. Med., 3: 119-123.

Guillard, R.L. - 1975. Culture of phytoplankton for feeding marine invertebrates. In: W.L. Smith and M.H. Chanley (eds.), Culture of marine invertebrates animals, pp. 29-60. Plenum Publishing, New York.

Helbling, E.W., B.E. Chalker, W.C. Dunlap, O. Holm-Hansen and V.E. Villafañe. - 1996. Photoacclimation of Antarctic marine diatoms to solar ultraviolet radiation. J. Exp. Mar. Biol. Ecol., 204: 85-101.

Hideg, E. and I. Vass. - 1996. UV-B induced free radical production in plant leaves and isolated thylakoid membranes. Plant Sci. 115: 251-/260.

Hernando, M. and N.A. San Roman. - 1999. Preliminary data on chronic effects of ultraviolet radiation on the growth of same phytoplankton species of the Beagle Channel, Argentina. Sci. Mar., 63(Suppl. 1): 81-88.

Hernando, M., G. Ferreyra, G. Malanga, S. Puntarulo and N. San Román. - 1998. Responses of Antarctic and Subantarctic phytoplankton to UV radiation. New Zealand natural sciences Antarctic ecosystems: Models for wider ecological understanding - Abstracts Handbook Vol. 23, Supplement, pp. 79.

Hernando, M., J.I. Carreto, M.O. Carignan, G.A. Ferreyra and C. Gross. - 2002. Effects of solar radiation on growth and mycosporine like amino acids content in antarctic diatom. Polar Biol., 25: 12-20.

Holm-Hansen, O. and B. Riemann. - 1978. Chlorophyll a determination: Improvements in methodology. Oikos, 30: 438-447.

Ichiki, H., H. Sakurada, N. Kamo, T.A. Takahashi and S. Sekiguchi. - 1994. Generation of active oxygens, cell deformation and membrane potential changes upon UV-B irradiation in human blood cells. Biol. Pharm. Bull., 17: 1065-1069.

Jagtap, V. and S. Bhargava. - 1995. Variation in the antioxidant metabolism of drought tolerant and drought susceptible varieties of Sorghum bicolor (L.) Moench exposed to high light, low water and high temperature stress. J. Plant Physiol., 145: 195-197.

Karentz, D., J.E. Cleaver and D.L. Mitchell. - 1991. Cell survival characteristics and molecular responses of Antarctic phytoplankton to ultraviolet-B radiation. J. Phycol., 27: 326-341.

Kingston-Smith, A.H. and C.H. Foyer. - 2000. Overexpression of Mn-superoxide dismutase in maize leaves leads to increased monodehydroascorbate reductase, dehydroascorbate reductase and glutathione reductase activities. J. Exp. Bot., 51: 1867-1877.

Lesser, M.P., J.J. Cullen and P.J. Neale. - 1994. Photoinhibition of 
photosynthesis in the marine diatom Thalassiossira pseudonono during acute exposure to ultraviolet $\mathrm{B}$ radiation: relative importance of damage and repair. J. Phycol., 30: 183192.

Lubin, D., J. Frederick, C. Booth, T. Lucas and D. Neuschuler. 1989. Measurement of enhaced springtime ultraviolet radiation at Palmer Station Antarctica. Geophys. Res. Lett., 16: 783-785.

Mackerness, A.H., S.L. Surplus, B.R. Jordan and B. Thomas. 1998 Effects of supplementary ultraviolet-B radiation on photosynthetic transcripts at different stages of leaves development and light levels in pea (Pisum sativum L.): role of active oxygen species and antioxidant enzymes. J. Photoch. Photobio., 68: 88-96.

Malanga, G. and S. Puntarulo. - 1995. Oxidative stress and antioxidant content in Chlorella vulgaris after exposure to ultravioletB radiation. Physiol. Plant., 94: 672-679.

Malanga, G., G. Calmanovici and S. Puntarulo. - 1997. Oxidative damage to chloroplasts from Chlorella vulgaris exposed to ultraviolet-B radiation. Physiol. Plant., 101: 455-462.

Martin, J.P. and P. Burch. - 1990. Production of oxygen radicals by photosensitization. Method. Enzymol., 186: 635-645.

Neale, P.J., E.W. Helbling and H.E. Zagarese. - 2002. Modulation of UV exposure and effects by vertical mixing and advection. In: E.W. Helbling and H. E. Zagarese (eds.), UV effects in aquatic organisms and ecosystems, pp. 107-134. Royal Society of Chemistry, Cambridge,UK.

Niyogi, K.K. - 1999. Photoprotection revisited: Genetic and molecular approches. Annu. Rev. Plant. Phys., 50: 333-359.

Orce L.V., N.A. San Roman, G. Rae, A. Paladini, J.C. Labraga, L.G. Buitrago, V.E. Villafañe and E.W. Helbling. - 1995. Latitudinal UV-Par Monitoring Network in Argentina. Proceedings of the WHO/WMO/NOAA/CIRES Conference.

Orce, L.V., N.A. San Román, A. Paladini, J. Labraga and E. Helbling. - 1997. Multiple regression fit. Latitudinal UVR-PAR measurements in Argentina: extent of the "ozone hole". Global and planetary change, 15: 113-121.

Pelle, E., G.A. Maes, E.K. Padulo, and W.P. Smith. - 1990. An in vitro model to test relative antioxidant potential: ultraviolet- induced lipid peroxidation in liposomes. Arch. Biochem. Biophys., 283: 234-240.

Plante, A.J. and M.T. Arts. - 2000. Effects of chronic, low levels of radiation on carbon allocation in Cryptomonas erosa and competition between $C$. erosa and bacteria in continuous cultures. J. Plankton Res., 22: 192-199.

Polle, A. and H. Rennenberg. - 1994. Photooxidative stress in trees. In: C.H. Foyer and P.M. Mullineaux (eds.), Causes of photooxidativestress and ameloration of defence systems in plants, pp. 199-218. CRC Press, London.

Predieri, S., H.A. Norman, D.T. Krizek, P. Pillai, R.M. Mirecki and R.H. Zimmerman. - 1995. Influence of UV-B radiation on membrane lipid composition and ethylene evolution in Doyunene D Hiber pea shoots grown in vitro under different photosynthetic photon fluxes. Environ. Exp. Bot., 35: 151-160.

Skerratt, J.H., A.D. Davidson, P.D. Nichols and T.A. McMeekin. 1998. Effect of UV-B on lipid content of three Antarctic marine phytoplankton. Phytochemistry, 49: 999-1007.

Salmon, S., J.C. Maziere, R. Santus, P. Morliere and N. Bouchemal - 1990. UV-B induced photoperoxidation of lipids of human LDL and HDL. A possible role of tryptophan residues. Photoch. Photobio., 52: 541-545.

Strid, A. - 1993. Alteration in expression of defence genes in Pisum sativum after exposure to supplementary ultraviolet-B radiation. Plant Cell Physiol., 34: 949-953.

Takeuchi, Y., R. Fukumoto, H. Kasahra, T. Sakaki and M. Kitao. 1995. Peroxidation of lipids and growth inhibition induced by UV-B irradiation. Plant Cell Rep., 14: 566-570.

Villafañe, V.E., E.W. Hebling, O. Holm-Hansen and B.E. Chalker. - 1995 Acclimatization of Antarctic natural phytoplankton assemblages when exposed to solar ultraviolet radiation. $J$. Plankton Res., 17: 2295-2306.

Yamashoji, S., H. Yoshida and G. Kajimoto. - 1979. Photooxidation of linoleic acid by ultraviolet light and effect of superoxide anion quencher. Agric. Biol. Chem., 43: 1249-1254.

Young, A.J., D. Phillip and J. Savill. - 1997. Carotenoids in higher plant photosynthesis. In: M. Pessaraki (ed.), Handbook of photosynthesis, pp. 575-596. Marcel Dekker, New York. 
